\title{
AACSB Accreditation in China---Current Situation, Problems, and Solutions
}

\author{
Xinrui Zhang (Corresponding author) \\ Business School, University of Shanghai for Science and Technology \\ 334 Jungong Road, Shanghai, China, 200093 \\ Tel: 86-21-65710296 E-mail: xr_zhang_usst@hotmail.com \\ Yan Gao \\ Business School, University of Shanghai for Science and Technology \\ 334 Jungong Road, Shanghai, China, 200093 \\ Tel:86-21-65710655Ｅ-mail: gaoyan@usst.edu.cn
}

Received: September 23, 2012

Accepted: October 10, $2012 \quad$ Online Published: November 13, 2012

doi:10.5430/ijhe.v1n2p210

URL: http://dx.doi.org/10.5430/ijhe.v1n2p210

\begin{abstract}
This paper first introduces the background of the AACSB accreditation, and then analyzes the current status of the participation of Chinese business schools in AACSB accreditation. Based on the data analysis, the paper points out that there are two main problems in the Chinese business schools AACSB accreditation: low participation rate and low success rate. The causes of these problems are concluded as language factor, standard factor as well as the misconception of the accreditation. Suggested solutions from the aspects of learning, communication, and ability enhance are given at the last part of the paper.
\end{abstract}

Keywords: AACSB accreditation, Current situation, Problems and solutions

\section{Literature review}

There are three authority accreditation systems for the business school quality evaluation worldwide: AACSB, EQUIS and AMBA. And AACSB is well known for its strict system and high standards, earned the respect and trust of many outstanding business schools, has member schools (Zhang, Jianru \& Zhao, Ping, 2006). According to the Best Business School Ranking of "Business Week" and "U.S. News and World Report" in 2006, the top 50 business schools in Europe, Asia, America are all AACSB accredited.

AACSB stands for The Association to Advance Collegiate Schools of Business; the association was founded in the United States in 1916 by 17 School of Business from the Universities including Columbia University, Cornell University, Harvard University, New York University, Northwestern University, Berkeley, University of California, University of Chicago, and headquartered in Tampa, Florida (in Tampa, Florida). From 1960 on, AACSB has become the most authoritative certification body for business school education quality accreditation, aimed at promoting the education quality and student enrollment standards of both accredited schools and accrediting schools (Cao, Liang \& Zhang, Rong, 2009)(Zhang, Yu, 2007).

After nearly a century's development, the specifications and evaluation criteria of the AACSB has become the authoritative standard of management education in the world. In an increasingly competitive, global market for leading business students and an ever-increasing number of business programs that deliver management education, differentiation is critical. According to the research results of Trapnell (2007), earning AACSB International accreditation can provide an important external validation and statement that can be an important factor in identifying high-quality business schools by prospective students, faculty, and employers(Jerry, E. Trapnell. 2007).

AACSB accreditation is important and useful for business schools to enhance their reputation and improve their education quality. But it is not easy to be accredited by AACSB International, to help business schools to get a better experience in the AACSB accreditation process, Bryant and Scherer (2009) suggested that a key factor in achieving initial AACSB accreditation is establishing an effective relationship between the mentor and the business school. 
They argued that if individual issues are not addressed during the development and implementation of the accreditation plan, time to initial accreditation can be increased substantially (Michael, Bryant \& Robert, F. Scherer. 2009). Some authors argue that AACSB should establishes different levels of accreditation, each having different standards and each having a different level of prestige. For example, White, Miles and Levernier (2009) suggested that AACSB could make the accreditation standards flexible, depending on the resources a school wanted to devote to business education, and the prestige that the school wished to achieve with accreditation (John, B. White, Morgan, P. Miles \& William, Levernier. 2009).

Compared with the businesses schools in the English speaking areas, the businesses schools in the non-English speaking areas meet more challenges, and the participate rate and success rate is much lower. This paper attempts to analyze the situation of Chinese business schools in AACSB accreditation, finds the problems and obstacles they meet, and based on the observation and critical analysis, the paper gives out some practical suggestions.

\section{Participation status of Chinese colleges and universities in the AACSB accreditation}

There are 4 stages in AACSB accreditation: membership application, pre-accreditation stage, the initial accreditation stage and accreditation maintain stage. And there are totally 1249 AACSB member institutions in the world (Source: AACSB official website: http://www.aacsb.edu), and in which only 639 members are accredited, the accreditation proportion is 51\%; in China, AACSB has 45 member business schools (including 8 Hong Kong institutions), but the accreditation proportion is only $13.5 \%$ (12 institutions are accredited, and including 7 Hong Kong). From this data, it can be seen that the business schools in China mainland are far behind the business schools in America, Europe, and even Hong Kong in the process of AACSB accreditation, the successful rate is even more backward (Table 1).

After reviewing and analyzing, we conclude that there are some history reasons for the low AACSB accreditation participation rate of Chinese colleges and universities: compared with the business schools in United States, Canada, United Kingdom, South Korea, Hong Kong, Taiwan and other countries and regions, China's domestic institutions recognize and understand the AACSB accreditation later, have a shorter period of time in understanding the standards and rules of AACSB, which is the most important reason leads to the obvious gap between Chinese business school and other business schools in the above areas in AACSB accreditation.

However, after gradually realized that the AACSB accreditation has a very important significance to improve the management philosophy of education, and to promote the continuous improvement of the quality of education, more and more business schools and colleges in China begin to participate in the AACSB accreditation process to improve their international status and influence. Currently, there are 37 AACSB member in China, such as: Peking University, People's University, Sun Yat-sen University, Xi'an Jiaotong University, Shanghai Jiaotong University, Nanjing University, Tongji University, Zhejiang University, Nankai University, etc. however, amog these 37 universities, there are only 5 universities have successfully passed AACSB accreditation: Tsinghua University, Fudan University, Shanghai Jiaotong University, Xi'an Jiaotong University, and China Europe International Business School.

\section{The problems faced by the Chinese colleges in AACSB accreditation}

Today, more and more Chinese colleges and universities begin to pay more emphasis on the AACSB accreditation to enhance and improve their education quality and reputation, more and more universities put AACSB accreditation as an important work for the next few years. However, we have to admit that compare with universities in other countries and regions such as United States, Canada, South Korea, Hong Kong, and Taiwan, China mainland has a lower proportion of participate rate as well as success rate. This paper tries to identify the problems faced by Chinese colleges and universities to participate in and get success in the AACSB accreditation. Three kinds of problems are analyzed and summarized as below:

\subsection{Language problem}

AACSB International was founded in the United States, all the standard and explanations are presented in English. After accepted as the AACSB member, the Association will send a mentor to help the university member to begin the following processes, the official language among the university, the mentor and the AACSB International is also in English, meanwhile, all the official files such as faculty handbook, student handbook, teaching materials, syllabus, test analysis, etc should be presented in English. But most Chinese Universities only have Chinese version of these files, to translate so many files into English is a huge and hard work considering the time, people, as well as finance aspects, therefore, this requirement highly prohibited the participation of Chinese universities in AACSB accreditation. 


\subsection{Standard understanding}

From the aspect of understanding AACSB accreditation standards, Chinese colleges and universities also face two major problems:

First, the AACSB accreditation standards are described in English, so how to translate and understand the standards accurately become an important issue for many Chinese colleges.

Secondly, there are significant differences in the education system and mechanisms between Chinese universities and United States universities, combined with the cultural differences between East and West, it makes Chinese universities somehow difficult to understand AACSB accreditation standards accurately.

\subsection{Misconception of the accreditation}

Due to historical reasons, majority colleges and universities in China has gone through a process of moving from the planned economy educational philosophy towards the market economy educational philosophy gradually, and still have some differences with the universities in Western countries. AACSB standards are people-centered, emphasis on students learning process and effects have both qualitative criteria and quantitative criteria, these factors require Chinese universities to reform their management philosophy and concepts in many aspects, for example, the business school should have a clear strategic mission, all teaching activities and research activities should be conducted based on the school's strategic mission, the business school should maintain continuous improvement.

\section{Suggested solutions}

According to the low participate rate and success rate of Chinese universities in AACSB accreditation, and based on the above analysis, we suggest that Chinese universities pay attention to the following 4 aspects:

\subsection{Improve language English skills}

As discussed above, language is a important reason that prohibits the Chinese universities to participate in AACSB accreditation, thus those Chinese universities that want to be successfully accredited by AACSB should improve the English skills of their faculty, staff as well as students.

\subsection{Wide range of AACSB accreditation standards learning}

AACSB standards are described detailed on its official website, and the association held many conferences as well as seminars to help its members to learn and to understand the relevant standards annually worldwide. Besides, business schools can learn AACSB standards through self-study, learn from other accredited universities or even communicate with AACSB association directly. Through extensive learning, Chinese universities can get a profound and correct understanding of the AACSB standards, thus lay a good foundation to the preparation for accreditation materials and meanwhile improve the quality of education and management.

\subsection{Strengthen communication}

AACSB will assign a mentor to each pre-accredited member to help the member institutions to understand the accreditation standards and processes better; the mentor is the bridge and ties between the member and AACSB. The member institutions should keep good and efficient communication with the mentor to help a smooth accreditation process. In addition, keep positive learning and communication with the accredited universities also help the smooth process of the accreditation. Finally, Chinese universities should strengthen communication inside itself, promote all faculty and staff to learn and understand the accreditation standards, avoid negative emotions, and create a good atmosphere to learn and implement the school's strategic mission.

\subsection{Improve Chinese Universities' own ability and strength}

The key factor to get AACSB accreditation successfully is to improve the education quality and management system in accordance with the AACSB standards, thus to strengthen Chinese universities' own capacity and to improve their education ability and strength. Chinese universities that want to be accredited by AACSB International should improve themselves in strategies, participates, and assurance of learning based on the AACSB accreditation standards.

\section{Conclusion}

In conclusion, the paper analyzes the current AACSB accreditation status of Chinese universities, based on the data analysis, the paper points out that there are two main problems in the Chinese business schools AACSB accreditation: low participation rate and low success rate. The causes of these problems are concluded as language factor, standard factor as well as the misconception of the accreditation. 4 suggestions from the aspects of language, learning, 
communication, and ability enhance are given at the end of the paper. We hope this paper can provide some hits to those Chinese universities that want to be AACSB accredited.

\section{References}

Cao, Liang \& Zhang, Rong. (2009). International management education accreditation. Managers. 19:56-58

Jerry, E. Trapnell. (2007). AACSB International accreditation: The value proposition and a look to the future, Journal of Management Development, Vol. 26 Issue: 1, pp.67-72. http://dx.doi.org/10.1108/02621710710720112

John, B. White, Morgan, P. Miles \& William, Levernier. (2009). AACSB International and the management of its brand: implications for the future, Journal of Management Development, Vol. 28 Issue: 5, pp.407-413. http://dx.doi.org/10.1108/02621710910955949

Michael, Bryant \& Robert, F. Scherer. (2009). Developing an Effective Mentor-Business School Relationship in the AACSB Initial Accreditation Process, American Journal of Business, Vol. 24 Issue: 1, pp.7-14.

Zhang, Jianru \& Zhao, Ping. (2006). Compare among AACSB International, AMBA and EQUIS, and the thoughts to MBA program in China. Academic Degrees and Graduate Education. 06:39-42

Zhang, Yu. (2007). International activities of Business School. Internet Weekly. 09:28-31

Table 1. Chinese universities' current status in the AACSB accreditation

\begin{tabular}{|l|c|c|c|}
\hline & China mainland only & China (with Hong Kong) & Global \\
\hline Accredited & 5 & 12 & 639 \\
\hline Member & 37 & 45 & 1249 \\
\hline Accredited rate & $13.5 \%$ & $26.7 \%$ & $51.2 \%$ \\
\hline
\end{tabular}

